\title{
Antibacterial Effect of the Scandium and Indium Complexes of Enterochelin on Escherichia coli
}

\author{
By HENRY J. ROGERS, * VIVIENNE E. WOODS AND CHARLOTTE SYNGE \\ National Institute for Medical Research, Mill Hill, London NW7 1AA, U.K.
}

(Received 5 November 1981: revised 19 February 1982)

\begin{abstract}
Enterochelin, the iron chelator produced by a number of pathogenic enterobacteria, appears to be an essential metabolite for multiplication within the host, where it transports iron from the host iron-binding proteins to the bacteria. Previous work showed that complexes of enterochelin containing either scandium $\left(\mathrm{Sc}^{3+}\right)$ or indium $\left(\mathrm{In}^{3+}\right)$ exerted a bacteriostatic effect on Klebsiella pneumoniae in serum, whilst the $\mathrm{Sc}^{3+}$ complex exerted a significant therapeutic effect on mice infected with $K$. pneumoniae. These observations have now been extended to a number of pathogenic serotypes of Escherichia coli including those carrying either the $\mathrm{K} 1$ antigen or the ColV plasmid. The $\mathrm{Sc}^{3+}$ and $\mathrm{In}^{3+}$ complexes each exert a bacteriostatic effect on these organisms growing in either whole serum or media containing an iron-binding protein. Evidence is presented that the $\mathrm{Sc}^{3+}$ complex may act as a competitive inhibitor of the $\mathrm{Fe}^{3+}$ complex. In contrast to their effects on $K$. pneumoniae, sideramines other than enterochelin fail to reverse the bacteriostatic effect of the $\mathrm{Sc}^{3+}$ complex of enterochelin in $E$. coli, suggesting that the complex produces a more profound derangement of metabolism in this organism. The $\mathrm{Sc}^{3+}$ complex exerts a significant therapeutic effect on $E$. coli infections in mice although the $\mathrm{In}^{3+}$ complex is less active.
\end{abstract}

\section{INTRODUCTION}

The physiochemical state of iron in body fluids is now considered to be of fundamental importance in host resistance to many bacterial infections (for general reviews of iron and infection see Bullen et al., 1978; and Weinberg, 1978). Bacteria entering the body become exposed to the iron-binding proteins, lactoferrin on mucosal surfaces and transferrin in the plasma. It has been postulated that in order to multiply in the presence of these iron-binding proteins, with which the ferric ion is very strongly associated (Aasa et al., 1963; Aisen \& Liebman, 1972), the bacteria must possess a specific mechanism for assimilating this proteinbound iron (Bullen et al., 1971).

Under iron-deficient conditions, a number of enterobacterial pathogens including Escherichia coli (Rogers et al., 1977), Salmonella typhimurium (Pollack \& Neilands, 1970) and Shigella sonnei (Perry \& San Clemente, 1979) secrete enterochelin, the cyclic trimer of 2,3-dihydroxy- $N$-benzoyl serine. This compound appears to be a virulence factor for both $E$. coli (Rogers, 1973) and $S$. typhimurium (Yancey et al., 1979). This idea is supported by the observations that enterochelin can remove $\mathrm{Fe}^{3+}$ from its complex with transferrin (Carrano \& Raymond, 1979) and that it can abolish the bacteriostatic effect of serum on E. coli (Rogers et al., 1977). Since enterochelin appears to be an essential growth factor for this important group of pathogens under the ironrestricted conditions imposed by the host, it was reasoned that complexes of enterochelin with ions other than $\mathrm{Fe}^{3+}$ might act as antimetabolites to ferric enterochelin. Of 19 complexes tested, only those containing either scandium or indium exerted a bacteriostatic effect on Klebsiella pneumoniae. The scandium complex exerted a therapeutic effect similar to that of kanamycin sulphate on $K$. pneumoniae infections in mice (Rogers et al., 1980). The present paper describes the antibacterial activity of these complexes on certain pathogenic serotypes of $E$. coli. A preliminary account of this work has been published (United Kingdom Patent 2022076, 1979). 


\section{METHODS}

Bacteria. Escherichia coli $\mathrm{O} 111 / \mathrm{K} 58 / \mathrm{H} 2$ was isolated from a case of neonatal gastro-enteritis whilst strain O141/K85/H4 was isolated from a scouring piglet. Serotypes O1/K1/H- (Sarff et al., 1975; provided by I. Ørskov, Statens Seruminstitute, DK 2300, Copenhagen 5, Denmark) and O18/K1/H7 ColV ${ }^{+}$(provided by H. Williams Smith, Houghton Poultry Research Station, Huntingdon, Cambs., U.K.) were isolated from cases of neonatal meningitis. Inocula were prepared and viable counts obtained as previously described (Rogers et al., 1980).

Sera. Normal rabbit serum was stored at $-20^{\circ} \mathrm{C}$. Heparinized rabbit plasma was heated for 30 min at $56^{\circ} \mathrm{C}$ and then stored at $-20^{\circ} \mathrm{C}$. Foetal calf serum and normal horse serum no. 2 were obtained in the frozen state (Wellcome Reagents) and stored at $-70^{\circ} \mathrm{C}$ and $-20^{\circ} \mathrm{C}$ respectively. Specific antiserum to $E$. coli $\mathrm{O} 111$ was prepared from a horse. The antiserum had an $\mathrm{O}$ agglutinating titre of $1: 8000$. Serum taken from the horse prior to immunization had a titre of $1: 16$ (Rogers, 1973).

Bacterial growth in serum and trypticase soy broth. Bacteria were grown in serum at $\mathrm{pH} 7 \cdot 4,37^{\circ} \mathrm{C}$, and viable counts were obtained on homogenized samples (Rogers, 1973). Trypticase soy broth (TSB; BBL Microbiology Systems) supplemented with $10 \mu \mathrm{M}$-ferrous ammonium sulphate and $1 \mu \mathrm{M}-\mathrm{MnCl}_{2}$, was also used in some experiments. The addition of $0.071 \mathrm{M}-\mathrm{NaHCO}_{3}$ under $5 \%(\mathrm{v} / \mathrm{v}) \mathrm{CO}_{2}$ in air at $37^{\circ} \mathrm{C}$ gave a $\mathrm{pH}$ of 7.5 .

Conalbumin. Conalbumin (Sigma, type I; $10 \mathrm{mg} \mathrm{m}^{-1}$ in $0.15 \mathrm{M}-\mathrm{NaCl}$ containing $0.02 \mathrm{M}-\mathrm{NaHCO}_{3}$ ) was dialysed for $24 \mathrm{~h}$ at $4{ }^{\circ} \mathrm{C}$ against the same solution to remove low molecular weight chelators. The conalbumin solution was sterilized by membrane filtration and stored at $-20^{\circ} \mathrm{C}$.

Enterochelin complexes. A $20 \mathrm{~mm}$ solution of enterochelin in n-butanone appeared to be stable at $-20^{\circ} \mathrm{C}$ for at least two months. Metal chlorides, final concentration $10 \mathrm{mM}$, were dissolved in $0 \cdot 1 \mathrm{M}-\mathrm{HCl} /$ ethanol mixture $(1 \mathrm{vol}$. $10 \mathrm{M}-\mathrm{HCl}$ to 99 vol. ethanol). For experiments in vitro, $0.2 \mathrm{~mm}$ solutions of the complexes were prepared daily by mixing $20 \mu \mathrm{l}$ of the enterochelin solution with $40 \mu \mathrm{l}$ metal chloride solution and then adding $1.94 \mathrm{ml}$ water followed by a few $\mathrm{mg}$ solid $\mathrm{NaHCO}_{3}$. Samples for the mouse protection tests were prepared by mixing $1.0 \mathrm{ml} 20 \mathrm{mM}$ enterochelin solution with $2.0 \mathrm{ml} 10 \mathrm{~mm}$-metal chloride solution. In the case of the $\mathrm{Sc}^{3+}$ complex, one drop of sterile glycerol was also added. After removing the solvent under vacuum, the residue was suspended by sonication in $20 \mathrm{ml}$ sterile $1 \% \mathrm{NaHCO}_{3}$ containing $0.85 \% \mathrm{NaCl}$. The $\mathrm{In}^{3+}$ complex formed a clear solution whilst the $\mathrm{Sc}^{3+}$ complex formed a fine suspension which settled out on standing but could be dispersed again by vigorous shaking. Without the additon of glycerol, the $\mathrm{Sc}^{3+}$ complex proved extremely difficult to wet and disperse. These solutions appeared to be stable for at least one week at $4{ }^{\circ} \mathrm{C}$. Solutions of the $\mathrm{Fe}^{3+}$ complex were prepared in the same way as the $\mathrm{In}^{3+}$ complex but appeared to undergo some decomposition within $24 \mathrm{~h}$.

Microbial iron chelators. Enterochelin, terregens factor, rhodotorulic acid and ferrioxamine B were all obtained as previously described by Rogers et al. (1980).

Haematin solution. A freshly prepared solution of $1 \mathrm{mM}$-haematin hydrochloride in $0.01 \mathrm{M}-\mathrm{NaOH}$ was added to heat-inactivated rabbit plasma to give a final concentration of $10 \mu \mathrm{M}$ immediately before inoculation with $E$. coli O111.

Mice. Female TO mice weighing $23-25 \mathrm{~g}$ were used.

\section{RESULTS}

\section{Antibacterial effects in serum}

The addition of either the $\mathrm{Sc}^{3+}$ or $\mathrm{In}^{3+}$ complexes of enterochelin $\left(2 \mu \mathrm{M} ; 1.4\right.$ and $1.6 \mu \mathrm{g} \mathrm{ml}^{-1}$ respectively) to normal rabbit serum in which $E$. coli $\mathrm{O} 141 \mathrm{had}$ been growing for $2 \mathrm{~h}$ inhibited further growth. In the case of the $\mathrm{Sc}^{3+}$ complex, this was followed by a bactericidal effect (Fig. 1). When heat-inactivated serum or plasma was used as a growth medium, addition of the complexes resulted in bacteriostasis. The $\mathrm{Sc}^{3+}$ complex of enterochelin also exerted a bacteriostatic effect on $E$. coli $\mathrm{O} 1 / \mathrm{K} 1$ growing in foetal calf serum. This experiment may be considered as a very simple model of neonatal septicaemia. The observation by Williams (1979) that a ColVlinked locus may enhance iron acquisition in invasive strains of $E$. coli prompted the testing of the $\mathrm{Sc}^{3+}$ complex $(2 \mu \mathrm{M})$ against one such strain $\left(E\right.$. coli $\left.\mathrm{O} 18 / \mathrm{K} 1 / \mathrm{H} 7 \mathrm{ColV}^{+}\right)$, growing in normal rabbit serum. The pattern of growth in the control and test samples was almost identical to that of $E$. coli $\mathrm{Ol} / \mathrm{K} 1$.

\section{Role of the iron-binding protein}

It was postulated that the ferric enterochelin uptake system would be induced by exposing the bacteria to the iron-binding proteins of the host. Only then would the bacteria become sensitive to the inhibitory effects of the $\mathrm{Sc}^{3+}$ complex. The data in Fig. 2 suggest that this is the case, since only a combination of iron-binding protein, in this case conalbumin, and the $\mathrm{Sc}^{3+}$ complex of 


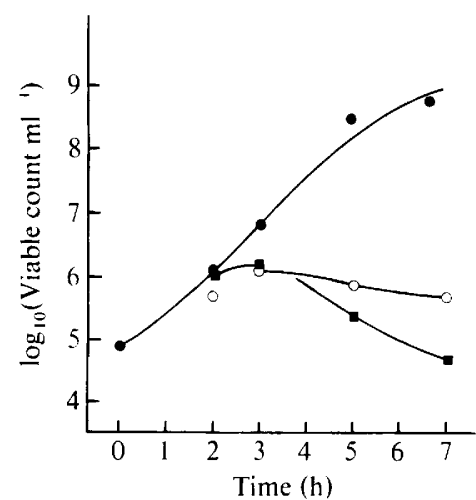

Fig. 1

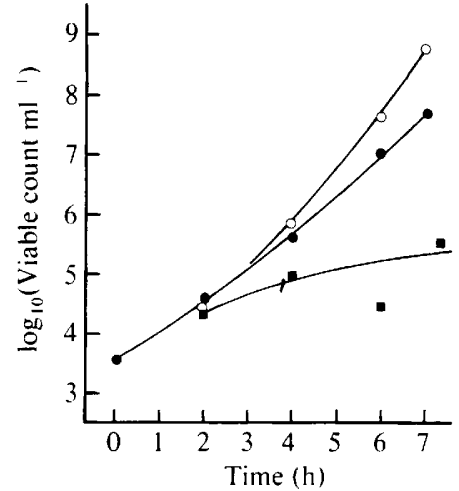

Fig. 2

Fig. 1. Antibacterial effect of complexes of enterochelin on $E$. coli $\mathrm{O} 141$ growing in normal rabbit serum. At $2 \mathrm{~h}$, the additions made were: none (control, $\bigcirc$ ); $2 \mu \mathrm{M}$-indium complex (O); $2 \mu \mathrm{M}$ scandium complex $(\mathbf{G})$.

Fig. 2. Effect of conalbumin $\left(1 \mathrm{mg} \mathrm{ml}^{-1}\right)$ and the scandium complex of enterochelin $(2 \mu \mathrm{M})$ on the growth of $E$. coli $\mathrm{O} 111$ in trypticase soy broth supplemented with $10 \mu \mathrm{M}-\mathrm{Fe}^{2+}$ and $1 \mu \mathrm{M}-\mathrm{Mn}^{2+}$. Growth: in TSB containing conalbumin (O); in TSB to which the scandium complex of enterochelin was added at $2 \mathrm{~h}(\mathrm{O})$; in TSB containing conalbumin to which the scandium complex of enterochelin was added at $2 \mathrm{~h}(\mathbf{\square})$.

Table 1. Growth of E. coli O111 in the presence of various enterochelin complexes

Normal horse serum containing $0.4 \%(\mathrm{v} / \mathrm{v}) 0111$ antiserum was inoculated with $E$. coli $\mathrm{O} 111$ to give an initial population of $3.5 \times 10^{2}$ organisms $\mathrm{ml}^{-1}$. Portions $(1.0 \mathrm{ml})$ were added to $25 \mathrm{ml}$ bottles containing the test sample (final concentration $2 \mu \mathrm{M}$ ). The bottles were incubated for $6 \mathrm{~h}$ on a rotary shaker at $37^{\circ} \mathrm{C}$ under a stream of moist $5 \%(\mathrm{v} / \mathrm{v}) \mathrm{CO}_{2}$ in air.

$\begin{array}{cc}\text { Complex } & \begin{array}{c}\text { Viable count } \\ \text { (no. of bacteria } \mathrm{ml}^{-1} \text { ) }\end{array} \\ \text { Control (no addition) } & <10^{3} \\ \mathrm{Fe}^{3+} & 2.3 \times 10^{7} \\ \mathrm{Al}^{3+} & 2.0 \times 10^{5} \\ \mathrm{Ga}^{3+} & 2.0 \times 10^{5} \\ \mathrm{In}^{3+} & <10^{3} \\ \mathrm{Sc}^{3+} & <10^{3} \\ \mathrm{Y}^{3+} & 2.1 \times 10^{6} \\ \mathrm{VO}^{2+} & 1.7 \times 10^{6} \\ \mathrm{Ti}^{4+} & 5.0 \times 10^{5} \\ \mathrm{Zr}^{4+} & 4.3 \times 10^{6}\end{array}$

enterochelin were capable of inhibiting the growth of $E$. coli O111 in TSB supplemented with $10 \mu \mathrm{M}-\mathrm{Fe}^{2+}$ and $1 \mu \mathrm{M}-\mathrm{Mn}^{2+}$.

\section{Stability of enterochelin complexes in serum}

Rogers et al. (1980) suggested that some complexes of enterochelin might decompose by exchanging their metal ion with serum transferrin. Since it is known that the bacteriostatic effect of specific antiserum on $E$. coli O111 can be reversed by enterochelin (Rogers et al., 1977), this property has been used in an attempt to differentiate between those complexes which are unstable and those which lack intrinsic antibacterial activity. The results presented in Table 1 show that the $\mathrm{VO}^{2+}, \mathrm{Y}^{3+}$ and $\mathrm{Zr}^{4+}$ complexes are quite active in stimulating bacterial growth.

\section{Effect of enterochelin on bacteriostasis}

Initial experiments showed that low concentrations of enterochelin $(0 \cdot 2 \mu \mathrm{M})$ failed to reverse the inhibitory effect of the $\mathrm{Sc}^{3+}$ complex $(2 \mu \mathrm{M})$ on $E$. coli $\mathrm{O} 141$ in rabbit plasma. Experiments in 


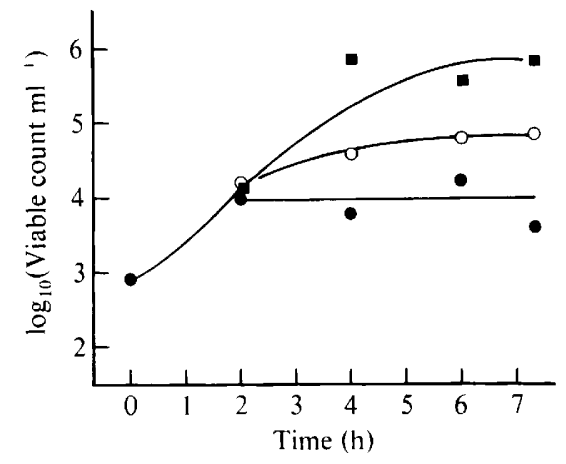

Fig. 3

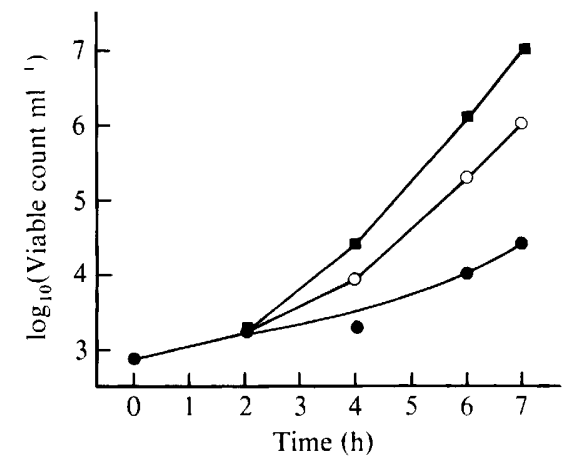

Fig. 4

Fig. 3. Effect of adding the scandium complex of enterochelin $(2 \mu \mathrm{M})$ at $2 \mathrm{~h}$ on the growth of $E$. coli O141 in heat-inactivated rabbit plasma containing enterochelin at $0 \cdot 2 \mu \mathrm{M}(O), 2 \mu \mathrm{M}(\mathrm{O})$ or $20 \mu \mathrm{M}(\mathbf{\square})$.

Fig. 4. Effect of adding ferric enterochelin at $2 \mathrm{~h}$ on the growth of $E$. coli O141 in heat-inactivated rabbit plasma containing the scandium complex of enterochelin $(2 \mu \mathrm{M})$ : none (control, $\bigcirc), 2 \mu \mathrm{M}$-ferric enterochelin $(O)$ and $20 \mu \mathrm{M}$-ferric enterochelin $(\square)$.

Table 2. Effect of enterochelin complexes on the survival times of mice infected with E. coli O141

Groups of 10 mice received $10^{7} \mathrm{E}$. coli $\mathrm{O} 141$ intraperitoneally and $1 \mathrm{~h}$ later were given $0.2 \mathrm{ml} 67 \mu \mathrm{M}$ solution of the complex by the same route. Deaths were recorded at $20 \mathrm{~min}$ intervals.

$\begin{array}{cc}\text { Complex } & \begin{array}{c}\text { Time to } 50 \% \\ \text { death }(\mathrm{h})\end{array} \\ \mathrm{Control} & 4 \cdot 75 \\ \mathrm{Al}^{3+} & 4 \cdot 75 \\ \mathrm{Ga}^{3+} & 3 \cdot 25 \\ \mathrm{In}^{3+} & 8 \cdot 5 \\ \mathrm{Sc}^{3+} & 7 \cdot 0 \\ \mathrm{Y}^{3+} & 4 \cdot 75 \\ \mathrm{La}^{3+} & 4 \cdot 25 \\ \mathrm{Co}^{2+} & 3 \cdot 5\end{array}$

which the bacteria were grown in the presence of different concentrations of enterochelin before adding the $\mathrm{Sc}^{3+}$ complex $(2 \mu \mathrm{M})$ showed that bacteriostasis still occurred after a $2 \mathrm{~h}$ delay even in the presence of a 10-fold excess of enterochelin (Fig. 3). An attempt was made to determine whether the $\mathrm{Fe}^{3+}$ and $\mathrm{Sc}^{3+}$ complexes of enterochelin act on the bacteria in a competitive manner. The inhibitory effect of the $\mathrm{Sc}^{3+}$ complex (at 0.2 or $2 \mu \mathrm{M}$ ) on E. coli $\mathrm{O} 141$ in rabbit plasma was rapidly reversed by the addition, $2 \mathrm{~h}$ later, of either $2 \mu \mathrm{M}$ or $20 \mu \mathrm{M}$ ferric enterochelin (Fig. 4).

\section{Effect of other ferric iron complexes}

Microbial iron-transporting compounds, including ferrioxamine B, ferric rhodotorulate, and particularly terregens factor, are all capable of reversing the inhibitory effect of the $\mathrm{Sc}^{3+}$ complex on $K$. pneumoniae (Rogers et al., 1980). In the case of E. coli O141 however, none of these compounds (at $10 \mu \mathrm{M}$ ) proved capable of reversing the bacteriostatic effect of $2 \mu \mathrm{M}-\mathrm{Sc}^{3+}$ complex. When added to the rabbit plasma at a concentration of $100 \mu \mathrm{M}$ at the beginning of the experiment, ferric ammonium citrate was able to prevent the bacteriostatic effect of both the $\mathrm{In}^{3+}$ and $\mathrm{Sc}^{3+}$ complexes of enterochelin $(2 \mu \mathrm{M})$ added $2 \mathrm{~h}$ later. Haematin $(10 \mu \mathrm{M})$ however, did not prevent these bacteriostatic effects (data not shown).

\section{Mouse protection tests}

Mice were infected by the intraperitoneal route with $1 \times 10^{7} \mathrm{E}$. coli $\mathrm{O} 141$ (approximately $1 \mathrm{LD}_{100}$ dose). They then received, $1 \mathrm{~h}$ later, $0.2 \mathrm{ml}$ of a $67 \mu \mathrm{M}$ solution [approximately $0.4 \mathrm{mg}$ 
( $\mathrm{kg}$ body weight $)^{-1}$ ] of various enterochelin complexes by the same route. Since mice given a lethal dose of the organism die within a few hours, deaths were recorded at 20 min intervals for the first $8 \mathrm{~h}$ after infection. The results in Table 2 show that of the complexes tested, only those of $\mathrm{Sc}^{3+}$ and $\mathrm{In}^{3+}$ were able to delay death.

In a further test of the protective effect of the $\mathrm{Sc}^{3+}$ complex, 40 mice were each infected with 8 $\times 10^{6}$ E. coli $\mathrm{O} 141$, and 20 animals received $0.2 \mathrm{ml}$ of $1 \mathrm{~mm}\left[5.8 \mathrm{mg}(\mathrm{kg} \text { body weight })^{-1}\right] \mathrm{Sc}^{3+}$ complex, 1 and $6 \mathrm{~h}$ after infection. Of the untreated mice which served as controls, $90 \%$ had died by $32 \mathrm{~h}$, whilst of the treated mice, $80 \%$ survived without obvious ill-effects and were killed one month later. In a similar test of the $\mathrm{In}^{3+}$ complex in mice receiving $1.2 \times 10^{7} \mathrm{E}$. coli $\mathrm{O} 141$, the lives of only a few animals were prolonged during the first $6 \mathrm{~h}$ of the experiment but there were no survivors from either group at $24 \mathrm{~h}$.

\section{DISCUSSION}

These observations provide further support for the idea that complexes of enterochelin with certain ions other than $\mathrm{Fe}^{3+}$ act as antimetabolites to ferric enterochelin and so inhibit bacterial multiplication by interfering with iron assimilation in the iron-restricted conditions imposed by the serum iron-binding protein, transferrin (Bullen et al., 1971). Thus, the growth of the four pathogenic serotypes of $E$. coli used in this work was inhibited by the $\mathrm{Sc}^{3+}$ complex of enterochelin (at $2 \mu \mathrm{M}$ ).

Although the $\mathrm{In}^{3+}$ complex is also active in vitro (Fig. 1), its properties have not been examined in great detail since it was less active in the mouse protection test. A bactericidal effect followed the addition of the $\mathrm{Sc}^{3+}$ complex to $E$. coli $\mathrm{O} 141$ in normal rabbit serum (Fig. 1). Heatinactivated serum or plasma in which only bacteriostasis occurs were used subsequently in order to avoid complications which might be imposed by this bactericidal effect. It would be of considerable importance, however, if inhibition by the complex were to render the bacteria more susceptible to the natural defences of the host.

Escherichia coli $\mathrm{O} 1 / \mathrm{K} 1$ growing in foetal calf serum was employed as a model of neonatal sepsis and meningitis (Sarff et al., 1975). The $\mathrm{Sc}^{3+}$ complex caused rapid inhibition of bacterial growth. Recent work by Williams (1979) suggests that certain invasive strains of E. coli carry a ColV plasmid which codes for an enhanced ability to sequester protein-bound $\mathrm{Fe}^{3+}$. This system appears to operate in addition to the enterochelin system of iron transport. It was found, however, that one such $\mathrm{ColV}^{+}$strain is just as susceptible to inhibition by the $\mathrm{Sc}^{3+}$ complex of enterochelin as serotypes $\mathrm{O} 141$ and $\mathrm{Ol}$.

An attempt has been made in this work to clarify some of the conditions required to render these compounds effective antibacterial agents. Thus, apart from the nature of the complexes themselves (Rogers et al., 1980), it was also postulated that an iron-restricted environment was required. A suitable iron-restricted environment was produced by means of conalbumin, the iron-binding protein from hen eggs. The ferric enterochelin transport system, which is induced by exposing the bacteria to suitable iron chelators (Rogers, 1973), is susceptible to inhibition by the $\mathrm{Sc}^{3+}$ complex of enterochelin (Fig. 2). This experiment, together with that carried out in foetal calf serum, also shows that antibody is not involved in the inhibitory process. Previous work showed that complexes of enterochelin containing either $\mathrm{Ru}^{3+}, \mathrm{VO}^{2+} \mathrm{or} \mathrm{Cr}^{3+}$ stimulated bacterial growth in serum, either as a result of hydrolysis of the complex or exchange reactions with transferrin resulting in free enterochelin (Rogers et al., 1980). Using E. coli O111 in which enterochelin release is blocked by specific antibody (Fitzgerald \& Rogers 1980), it has been possible to obtain some indication of the stability of the complexes in serum (Table 1). Thus, the growth in the presence of $\mathrm{Y}^{3+}$ complex is in accord with its chemical instability. Although the $\mathrm{VO}^{2+}, \mathrm{Ti}^{4+}$ and $\mathrm{Zr}^{4+}$ complexes are moderately stable to decomposition by $\mathrm{Fe}^{3+}$ (Rogers et al., 1980), they appear to release sufficient enterochelin in serum to support considerable bacterial growth.

The inhibitory effect of $\mathrm{Sc}^{3+}$ enterochelin on bacterial growth can be reversed by relatively high concentrations of the $\mathrm{Fe}^{3+}$ complex in a manner that suggests competition between the complexes. The failure of metal-free enterochelin $(20 \mu \mathrm{M})$ to reverse the inhibitory effect could 
then be explained by its inability to remove sufficient iron from transferrin to compete with the $\mathrm{Sc}^{3+}$ complex. This, in turn, suggests that in order to overcome the inhibitory effect of the complex, the organism would have to produce very high levels of enterochelin. In the case of $E$. coli $\mathrm{O} 141$ growing in serum, the maximum concentration of enterochelin attained was found to be only $0.48 \mu \mathrm{M}$ (Rogers, 1973).

Previous work has shown that a number of microbial iron transporting compounds could reverse the bacteriostatic effect of the $\mathrm{Sc}^{3+}$ complex on $K$. pneumoniae (Rogers et al., 1980). In contrast, these compounds failed to reverse the inhibitory effect of the complex on E. coli O141. This suggests that exposing the organism to the $\mathrm{Sc}^{3+}$ complex may induce biochemical changes beyond an interruption of the iron supply. The $\mathrm{In}^{3+}$ complex appears to exert similar effects. Both ferric ammonium citrate and haematin abolish the bacteriostatic effect of serum on E. coli O141 (Bullen \& Rogers, 1969). In contrast, only the former proved capable of preventing the bacteriostatic effect of the complexes on the organism. It is probable that the initial exposure of the bacteria to ferric ammonium citrate served to repress the ferric enterochelin system thus making the bacteria insensitive to the complexes.

The results of preliminary mouse protection tests (Table 2) and experiments in vitro show that the antibacterial properties are confined to the $\mathrm{In}^{3+}$ and $\mathrm{Sc}^{3+}$ complexes of enterochelin. Definitive tests have shown that, as in the case of $K$. pneumoniae (Rogers et al., 1980), the $\mathrm{In}^{3+}$ complex has only a slight therapeutic effect on $E$. coli $\mathrm{O} 141$ infections in mice whilst the $\mathrm{Sc}^{3+}$ complex exerts a significant therapeutic effect.

\section{REFERENCES}

Aasa, R., Malmstrom, B. G., Saltman, P. \& VÄNNGÅRD, T. (1963). The specific binding of iron (III) and copper (II) to transferrin and conalbumin. Biochimica et biophysica acta 75, 203-222.

Aisen, P. \& Leibman, A. (1972). Lactoferrin and transferrin: a comparative study. Biochimica et biophysica acta 257, 314-323.

Bullen, J. J. \& Rogers, H. J. (1969). Bacterial iron metabolism and immunity to Pasteurella septica and Escherichia coli. Nature, London 224, 380-382.

Bullen, J. J., Rogers, H. J. \& Griffiths, E. (1978). Role of iron in bacterial infection. Current Topics in Microbiology and Immunology 80, 1-35.

Bullen, J. J., Rogers, H. J. \& Lewin, J. E. (1971). The bacteriostatic effect of serum on Pasteurella septica and its abolition by iron compounds. Immunology 20, 391-406.

Carrano, C. J. \& Raymond, K. N. (1979). Ferric ion sequestering agents. 2. Kinetics and mechanism of iron removal from transferrin by enterobactin and synthetic tricatechols. Journal of the American Chemical Society 101, 5401-5404.

Fitzgerald, S. P. \& Rogers, H. J. (1980). Bacteriostatic effect of serum: role of antibody to lipopolysaccharide. Infection and Immunity 27, 302-308.

Perry, R. D. \& San Clemente, C. L. (1979). Siderophore synthesis in Klebsiella pneumoniae and Shigella sonnei during iron deficiency. Journal of Bacteriology 140, 1129-1132.
Pollack, J. R. \& Neilands, J. B. (1970). Enterobactin, an iron transport compound from Salmonella typhimurium. Biochemical and Biophysical Research Communications 38, 989-992.

ROGERS, H. J. (1973). Iron-binding catechols and virulence in Escherichia coli. Infection and Immunity 7, 445-456.

Rogers, H. J., Synge, C., Kimber, B. \& BAyley, P. M. (1977). Production of enterochelin by Escherichia coli O111. Biochimica et biophysica acta 497, 548-557.

Rogers, H. J., Synge, C. \& Woods, V. E. (1980). Antibacterial effect of the scandium and indium complexes of enterochelin on Klebsiella pneumoniae. Antimicrobial Agents and Chemotherapy 18, 63-68.

SARfF, L. D., McCracken, G. H., Schiffer, M. S., Glode, M. P., RobBINS, J. B., ØrSKov, I. \& ØRSKov, T. (1975). Epidemiology of Escherichia coli $\mathrm{K} 1$ in healthy and diseased newborns. Lancet 1, 1099 1104.

Williams, P. H. (1979). Novel iron uptake system specified by ColV plasmids. An important component in the virulence of invasive strains of Escherichia coli. Infection and Immunity 26, 925-932.

WeinberG, E. D. (1978). Iron and infection. Microbiological Reviews 42, 45-66.

YANCEY, R. J., Breeding, S. A. E. L. \& LANKFord, C. E. (1979). Enterochelin (enterobactin) virulence factor for Salmonella typhimurium. Infection and Immunity 24, 174-180. 